\title{
PELAKSANAAN PENEGAKAN HUKUM BAGI ANGGOTA KEPOLISIAN YANG MELANGGAR KODE ETIK DALAM PENYALAHGUNAAN NARKOTIKA
}

\author{
Umar Dinata
}

Universitas Jambi, Indonesia, umar.dinata999@gmail.com

\begin{abstract}
The problem of Narcotics abuse in Indonesia, is now very concerning, Indonesian people and even the world community in general are currently faced with a very worrying situation due to rampant illegal use of various types of Narcotics. The functions and duties of the State Police of the Republic of Indonesia have been regulated in several statutory provisions. In this case Law Number 2 of 2002 concerning the State Police of the Republic of Indonesia extends the functions and duties of the Police which include maintaining security and public order, law enforcement, protection and protection and services to the community by upholding human rights, but there are several police officers who even abuse their authority by participating in the use and distribution of illegal drugs or drugs. This of course can lead to the loss of public trust in the police to guarantee legal certainty or provide legal protection for the community. The problem is how is the law enforcement for members of the police who violate the code of ethics, and what obstacles and efforts are faced in enforcing the law against members of the police who violate the code of ethics and professional code of ethics for the police as regulated in the Chief of Police Regulation No. 7 of 2006 and National Police Regulation No. 8 of 2006, are moral principles with the hope of growing high commitment for all members of the National Police to obey and implement the Police Professional Code of Ethics, but the fact remains that there are members of the National Police acting otherwise which are not in accordance with police professional ethics, Instead of violating the code of ethics, such as an example of drug abuse, which of course violates the Polri's code of ethics, law enforcement must be carried out in accordance with existing laws and of course with the code of ethics owned by the Police or by means of applicable legal rules. -factors faced in law enforcement against police who violate the code of ethics, as well as facilities and infrastructure factors, efforts to handle them by using regulations in accordance with the prevailing laws. and the addition of new members of the National Police of course helped with this.
\end{abstract}

Keywords: Code of Ethics, Narcotics, Police

\begin{abstract}
Abstrak
Masalah penyalahgunaan Narkotika di Indonesia, sekarang ini sudah sangat memprihatinkan, Masyarakat Indonesia bahkan masyarakat dunia pada umumnya saat ini sedang dihadapkan pada keadaan yang sangat mengkhawatirkan akibat maraknya pemakaian secara illegal bermacam-macam jenis Narkotika. fungsi dan tugas Kepolisian Negara Republik Indonesia telah diatur didalam beberapa ketentuan peraturan perundang-undangan. Dalam hal ini Undang-Undang Nomor 2 Tahun 2002 tentang Kepolisian Negara Republik Indonesia memperluas fungsi dan tugas Kepolisian yang meliputi pemeliharaan keamanan dan ketertiban
\end{abstract}


masyarakat, penegakan hukum perlindungan dan pengayoman dan pelayanan kepada masyarakat dengan menjunjung tinggi Hak Asasi Manusia, namun Ada beberapa oknum polisi yang bahkan menyalahgunakan wewenangnya dengan ikut menggunakan dan mengedarkan obat-obatan terlarang atau narkoba. Hal tersebut tentu saja dapat menyebabkan hilangnya rasa percaya masyarakat kepada polisi untuk memberikan jaminan kepastian hukum atau memberikan perlindungan hukum terhadap masyarakat. Adapun yang menjadi permasalahannya adalah Bagaimanakah Penegakan Hukum Bagi Anggota Kepolisian Yang Melanggar Kode Etik, dan apa hambatan serta upaya yang dihadapi dalam Penegakan Hukum terhadap Anggota Kepolisian Yang Melanggar Kode Etik, Kode Etik Profesi Polri sebagaimana diatur dalam Peraturan Kapolri No. 7 tahun 2006 dan Peraturan Kapolri No.8 Tahun 2006, merupakan kaidah moral dengan harapan tumbuhnya komitmen yang tinggi bagi seluruh anggota Polri agar mentaati dan melaksanakan Kode Etik Profesi Polri, namun kenyataan masi adanya anggota polri bertindak sebaliknya yang tidak sesuai dengan etika profesi kepolisian, justru melakukan pelanggaran kode etik seperti salah satu contoh penyalahgunaan narkoba, yang tentu saja melanggar kode etik Polri, maka penegakan hukum harus dilaksanakan sesuai dengan hukum yang ada dan tentu saja dengan kode etik yang dimiliki oleh Polri atau dengan cara melalui aturan hukum yang berlaku, Faktor-faktor yang dihadapi dalam penegakan hukum terhadap polisi yang melanggar kode etik, serta faktor sarana dan prasarana, upaya dalam penangananya dengan cara memakai peraturan-peraturan sesuai dengan yang berlaku. dan penambahan anggota Polri yang baru tentu saja membantu hal tersebut.

Kata kunci: Kode Etik, Narkotika, Polri

\section{A. Pendahuluan}

Narkotika diperlukan oleh manusia untuk pengobatan sehingga untuk memenuhi kebutuhan dalam bidang pengobatan dan studi ilmiah diperlukan suatu produksi Narkotika yang terus menerus untuk para penderita tersebut. Masalah penyalahgunaan Narkotika di Indonesia, sekarang ini sudah sangat memprihatinkan. Hal ini disebabkan beberapa hal antara lain karena Indonesia yang terletak pada posisi di antara tiga benua dan mengingat perkembangan ilmu pengetahuan dan teknologi, maka pengaruh globalisasi, arus transportasi yang sangat maju dan penggeseran nilai matrialistis dengan dinamika sasaran opini peredaran gelap. ${ }^{1}$ Masyarakat Indonesia bahkan masyarakat dunia pada umumnya saat ini sedang dihadapkan pada keadaan yang sangat mengkhawatirkan akibat maraknya pemakaian secara illegal bermacam-macam jenis Narkotika. Kekhawatiran ini semakin

\footnotetext{
${ }^{1}$ Juliana Lisa, Nengah Sutrisna., Narkoba, Psikotropika Dan Gangguan Jiwa, (Yogyakarta: Nuha Medika, 2003), hlm. 1.
} 
di pertajam akibat maraknya peredaran gelap Narkotika yang telah merebak di segala lapisan masyarakat, termasuk di kalangan generasi muda.

Setiap negara hukum memiliki aparat penegak hukum termasuk kepolisian yang secara universal mempunyai tugas dan fungsi menjaga keamanan dan ketertiban masyarakat sesuai dengan ketentuan ketentuan Hukum yang berlaku untuk mewujudkan kepastian Hukum dan keadilan,fungsi dan tugas Kepolisian Negara Republik Indonesia telah diatur didalam beberapa ketentuan peraturan perundangundangan. Undang-Undang Nomor 2 Tahun 2002 tentang Kepolisian Negara Republik Indonesia memperluas fungsi dan tugas Kepolisian yang meliputi pemeliharaan keamanan dan ketertiban masyarakat, penegakan hukum perlindungan dan pengayoman dan pelayanan kepada masyarakat dengan menjunjung tinggi Hak Asasi Manusia. ${ }^{2}$

Berdasarkan salah satu Asas Hukum yang dijadikan sebagai acauan terhadap berlakunya suatu peraturan perundangundangan, Yakni Lex Specialis Derogat Legi Generale, maka untuk menjerat pelaku penyalahgunaan narkotika digunakanlah Undang-Undang Nomor 35 Tahun 2009 tentang Narkotika yang sifatnya lebih khusus. Salah satu upaya untuk memberantas penyalahgunaan Narkotika adalah dengan mencari dan membasmi asal muasal atau yang memproduksi barang tersebut sehingga para pemakainya kesulitan untuk mendapatkan narkotika itu. ${ }^{3}$

Penerapan pidana ganda dalam tindak pidana Narkotika diatur Dalam UndangUndang Nomor 35 Tahun 2009 tentang Narkotika, yaitu pada Pasal 111 sampai dengan Pasal 127. Dalam Pasal 111 ayat (1)

\footnotetext{
${ }^{2}$ Sadjijono, Memahami Hukum Kepolisian, (Yogyakarta: Laksbang Pressindo, 2010), hlm. 1.

${ }^{3}$ Moh. Taufik Makarao, Suhasril, dan H. Moh Zakky., Tindak Pidana Narkotika, (Jakarta: Ghalia Indonesia, 2003), hlm. 1.
} 
dijelaskan bahwa Setiap orang yang tanpa hak atau melawan hukum menanam, memelihara, memiliki, menyimpan, menguasai, atau menyediakan Narkotika Golongan I dalam bentuk tanaman, dipidana dengan pidana penjara paling singkat 4 (empat) tahun dan paling lama 12 (dua belas) tahun dan pidana denda paling sedikit Rp.800.000.000,00 (delapan ratus juta rupiah) dan paling banyak Rp.8.000.000.000,00 (delapan miliar rupiah)."

Seperti yang terdapat dalam Peraturan Kepala Kepolisian Negara Republik Indonesia Nomor 14 tahun 2011 Tentang Kode Etik Profesi Kepolisian Negara Republik Indonesia dalam Pasal 1 angka 11: "Penegakan KEPP adalah serangkaian tindakan pejabat Polri yang diberi kewenangan menurut peraturan ini, untuk melakukan pemeriksaan pendahuluan, pemeriksaan di Sidang KKEP, pemeriksaan Sidang Komisi Banding Kode Etik Polri terhadap Anggota Polri yang diduga melakukan Pelanggaran KEPP dan rehabilitasi Anggota Polri yang dinyatakan sebagai Pelanggar atau tidak terbukti sebagai Pelanggar, ”. Pasal 1 angka 17: "Pemberhentian Tidak Dengan Hormat yang selanjutnya disingkat PTDH adalah pengakhiran masa dinas kepolisian oleh pejabat yang berwenang terhadap seorang Anggota Polri karena telah terbukti melakukan Pelanggaran KEPP, disiplin, dan/ atau tindak pidana".

Polisi sebagai pelaksana dan penegak hukum mempunyai tugas memelihara keamanan dalam negara Republik Indonesia serta diberikan kewenangan untuk melakukan pencegahan dan pemberantasan tindak pidana. Keberadaan polisi sebagai ujung tombak dalam posisi awal pelaksanaa sistem peradilan wajib melakukan tugas dan wewenang sebagai penegak hukum. Ada beberapa oknum polisi yang bahkan menyalahgunakan wewenangnya dengan 
ikut menggunakan dan mengedarkan obatobatan terlarang atau narkoba. Hal tersebut tentu saja dapat menyebabkan hilangnya rasa percaya masyarakat kepada polisi untuk memberikan jaminan kepastian hukum atau memberikan perlindungan hukum terhadap masyarakat.

Dalam hal ini polisi telah melakukan penyalahgunaan jabatan, tugas serta wewenangnya. Seharusnya mereka bertugas untuk memberikan panutan kepada masyarakat, memberikan contoh yang baik bahkan ikut serta dalam proses pemberantasan kejahatan narkotika. Namun sebaliknya jika mereka ikut serta dalam tindakan menyalahgunakan narkotika, tentu saja dapat memberikan kesan atau pandangan negatif terhadap citra polisi itu sendiri.

\section{Rumusan Masalah}

1. Bagaimana Penegakan Hukum Bagi Anggota Kepolisian Yang Melanggar Kode Etik
2. Faktor penghambatan dalam Penegakan Hukum terhadap Anggota Kepolisian Yang Melanggar Kode Etik

3. Upaya yang dilakukan untuk mengatasi faktor-faktor dalam Penegakan Hukum Bagi Anggota Kepolisian Yang Melanggar Kode Etik

\section{Metode Penelitian}

Pada metode penelitian ini, peneliti memaparkan jenis penelitian yang digunakan (normatif atau empiris), metode pendekatan (perundang-undangan, kasus, perbandingan, historis, dll) sumber data ( data primer, data sekunder), cara pengambilan data, lokasi penelitian, alasan pemilihan lokasi penelitian, dan juga memberikan teknik analisis data.

\section{B. Hasil Penelitian dan Pembahasan}

1. Penegakan Hukum Bagi Anggota Kepolisian Yang Melanggar Kode Etik 
Polisi adalah aparat penegak hukum. Tetapi dalam kenyataan yang terjadi ada sebagian anggota itu bertindak sebaliknya dan tidak sesuai dengan etika profesi kepolisian. Atau dalam arti kata ada sebagian polisi melakukan pelanggaran terhadap kode etik profesi kepolisian. Pelanggaran ataupun perbuatan pidana anggota kepolisian yang tidak sesuai dengan kode etik kepolisian ini tentunya berakibat hukum. Permasalahan kedua dapat diberikan jawaban bahwa penyelesaian pelanggaran kode etik profesi kepolisian yang mengakibatkan terjadinya tindak pidana.

Ketentuan mengenai Kode Etik Profesi Polri sebagaimana diatur dalam Peraturan Kapolri No. 7 tahun 2006 dan Peraturan Kapolri No.8 Tahun 2006, merupakan kaidah moral dengan harapan tumbuhnya komitmen yang tinggi bagi seluruh anggota Polri agar mentaati dan melaksanakan (mengamalkan) Kode Etik Profesi Polri dalam segala kehidupan, yaitu dalam pelaksanaan tugas, dalam kehidupan sehari-hari dan dalam pengabdian kepada masyarakat, bangsa dan negara. ${ }^{4}$

Kode etik profesi adalah suatu tuntutan, bimbingan atau pedoman moral atau kesusilaan untuk suatu profesi tertentu atau merupakan daftar kewajiban dalam menjalankan suatu profesi yang disusun oleh para anggota profesi itu sendiri dan mengikat mereka dalam praktek. Dengan demikian maka kode etika profesi berisi nilai-nilai etis yang ditetapkan sebagai sarana pembimbing dan pengendali bagaimana seharusnya atau seyogyanya pemegang profesi bertindak atau berperilaku atau berbuat dalam menjalankan profesinya. Jadi, nilai-nilai yang terkandung dalam kode etik profesi adalah nilai-nilai etis. ${ }^{5}$

Kode etik profesi lahir dari dalam lembaga atau organisasi profesi itu sendiri

\footnotetext{
4 Yanius Rajalahu, Penyelesaian Pelanggaran Kode Etik Profesi Oleh Kepolisian Republik Indonesia, (Jurnal Lex Crimen Vol 11/No.2,2013) , hlm 143

5 H.Pudi Rahardi,Hukum Kepolisian, Profesionalisme dan Reformasi Polri.(Surabaya: Laksbang Mediatama 2007) hlm. 146.
} 
yang kemudian mengikat secara moral bagi seluruh anggota yang tergabung dalam organisasi profesi yang satu dengan organisasi lainnya memiliki rumusan kode etik profesi yang berbeda-beda, baik unsur normanya maupun ruang lingkup dan wilayah berlakunya. Demikian pula pada profesi kepolisian, mempunyai kode etik yang berlaku bagi polisi dan pemegang fungsi kepolisian. Kode etik bagi profesi kepolisian tidak hanya didasarkan pada kebutuhan profesional, tetapi juga telah diatur secara normatif dalam Undangundang (UU) No. 2 Tahun 2002 tentang Polri yang ditindaklanjuti dengan Peraturan Kapolri, dalam Pasal 4 UU No. 2 Tahun 2002 menjelaskan bahwa Kepolisian Negara Republik Indonesia bertujuan untuk mewujudkan keamanan dalam negeri yang meliputi terpeliharanya keamanan dan ketertiban masyarakat, tertib dan tegaknya hukum, terselenggaranya perlindungan, pengayoman, dan pelayanan kepada masyarakat, serta terbinanya ketentraman masyarakat dengan menjunjung tinggi hak asasi manusia, sehingga Kode Etik Profesi Polri berlaku mengikat bagi setiap anggota Polri.

Dalam Pasal 34 dan 35 UU No. 2 Tahun 2002 disebutkan bahwa:

a. Sikap dan perilaku pejabat Polri terikat pada Kode Etik Profesi Polri; Kode Etik profesi Polri dapat menjadi pedoman bagi pengemban fungsi kepolisian lainnya dalam melaksanakan tugas sesuai dengan peraturan perundang-undangan yang berlaku di lingkungan polri; dan

b. Ketentuan mengenai Kode Etik Profesi Polri diatur dengan keputusan Kapolri. Selanjutnya dalam Pasal 35 disebutkan: (1) pelanggaran terhadap Kode Etik Profesi Polri oleh pejabat Polri diselesaikan oleh Komisi Kode Etik Polri; dan 
c. Ketentuan mengenai susunan organisasi dan tata kerja Komisi Kode Etik Polri diatur dengan keputusan Kapolri. Selanjutnya dalam Pasal 35 disebutkan: (1) pelanggaran terhadap kode etik profesi Polri oleh pejabat Polri diselesaikan oleh Komisi Kode Etik Polri; dan (2) ketentuan mengenai susunan organisasi dan tata kerja Komisi Kode Etik Polri diatur dengan Kapolri.

Polisi adalah aparat penegak hukum.

Tetapi dalam kenyataan yang terjadi ada sebagian anggota itu bertindak sebaliknya dan tidak sesuai dengan etika profesi kepolisian. Atau dalam arti kata ada sebagian polisi melakukan pelanggaran terhadap kode etik profesi kepolisian Dalam pelanggaran kode etik seperti salah satu contoh penyalahgunaan narkoba, yang tentu saja melanggar kode etik Polri, maka penegakan hukum harus dilaksanakan sesuai dengan hukum yang ada dan tentu saja dengan kode etik yang dimiliki oleh Polri. Maroef sebagaimana mengutip pendapat seorang psikiater Graham Blaine menyatakan bahwa terdapat beberapa sebab terjadinya penyalahgunaan Narkotika yaitu: ${ }^{6}$

a. Karena dorongan dan rasa ingin tahu dan rasa iseng;

b. Untuk meningkatkan rasa kepemilikan antar sesama;

c. Untuk menunjukan keberanian di dalam kelompok;

d. Membuat berusaha agar menemukan arti hidup;

e. Bentuk penolakan terhadap kebiasaan yang dilakukan seharihari;

f. Untuk mengisi kekosongan dan mengisi perasaan bosan karena kesibukan;

g. Untuk memuaskan nafsu seks; 
h. Melepaskan rasa kesendirian dengan membentuk kelompok lainnya;

Dikaitkan pendapat Blaime sebelumnya, dan beridasarkan pada tiga keterangan yang penulis dapat dari mantan anggota polisi Polres Pelalawan yang melanggar kode etik dalam penggunaan narkotika, bahwa mereka pada umumnya menyalahgunakan narkotika tersebut akibat dari membuat berani, dan untuk mengisi kekosongan dan rasa bosan, pendapat mereka ini sesuai dengan Blaime sampaikan sebelumnya.

Keterkaitan antara jabatan penegak hukum dengan sekaligus sebagai pelaku tindak pidana dapat saja diberikan bentuk hukuman yang diperberat sepertiga sesuai Pasal 54 KUHP. Hal ini didasarkan dengan pelaku tindak pidana merupakan pejabat negara sehingga hal ini merupakan bentuk tanggungjawab dari pada pejabat bersangkutan terhadap tindakannya yang melanggar hukum. Berbagai peraturan telah dikeluarkan oleh pemerintahan khususnya dalam kaitannya dalam tindak pidana narkotika, bahkan bukan hanya masyarakat umum yang terlibat dalam penyalahgunaan Narkotika, namun melainkan anggota kepolisian yang mana seharusnya kedudukannnya sebagai aparat penegak hukum.

Penegakan hukum diartikan sebagai suatu proses untuk mewujudkan keinginankeinginan hukum yaitu pikiran-pikiran dari badan-badan pembuat undang-undang yang dirumuskan dan ditetapkan dalam peraturanperaturan hukum yang kemudian menjadi kenyataan. $^{7}$ Penegakan hukum juga dapat saja dipahami sebgai pengharmonisan antara nilainilai yang telah diuraikan di dalam kaidahkaidah hukum yang kokoh serta penguraian dengan rasa dan tindak yang merupkan bagian dari uraian nilai-nilai akhir berupa keadilan guna memelihara kedamaian itu sendiri. Dengan uraian

\footnotetext{
${ }^{7}$ Rahardjo, Loc.Cit
} 
tersebut letak penegakan hukum dapat dirasakan di bentuk pendekatan sosial. ${ }^{8}$

Bagian daripada penegakan hukum dapat saja diuraikan menjadi tiga bagian yakni berupa peraturan perundang-undangan merupakan sekumpulan aturan hukum positif yang dikodifikasi dan tertulis yang dituangkan dalam lembaran negara untuk ditetapkan. Kedua berikaitan dengan penegak hukum yakni empat (4) pilar penegak hukum yakni hakim, jaksa, advokat dan polisi. Serta ketiga yang terpenting adalah masyarakat selaku subjek hukum yang dituntut kesadarannya untuk hukum. Penegakan hukum terhadap anggota Kepolisian yang telah terbukti melakukan tindak pidana khususnya tindak pidana narkotika maka penyelesaian perkaranya sama dengan masyarakat pada umumnya yaitu melalui peradilan umum. Selain peradilan umum anggota polisi yang melakukan tindak pidana juga akan ada

\footnotetext{
${ }^{8}$ Soekanto, Loc.Cit
}

tambahan lain yaitu dari internal Kepolisian sendiri yang berupa penegakan hukum melalui sidang kode etik polisi.

Adapun uraian proses penegakan hukum polisi yang melakukan tindak pidana narkotika adalah:

\section{a. Tahap Penyilidikan}

Dalam tahap penyelidikan ini anggota kepolisian yang diduga melakukan tindak pidana penyalahgunaan Narkotika dapat dilaporkan dengan dan dari aduan masyarakat. Dengan adanya aduan ini akan ditindak lanjuti kepada pimpinan kepolisian terkait selanjutnya disampaikan pada unit Provos masing-masing untuk melakukan penyelidikan. Dengan adanya alat bukti yang dianggap kuat makan dari unit Provos menyerahkan penyelidikan kepada Unit Paminal untuk melanjutkan penyelidikan dalam penyelidikan ini bukan saja unit Paminan tetapi unit Reskrim juga ikut dalam proses penyelidikan. Setelah unit Paminal menganggap bukti terkumpul kuat maka 
akan diserahkan kembali pada unit Provos guna lanjut kepada penyidikan terhadap pelanggaran kode etik kepolisian. Di sisi lain unit Reskrim juga menlanjtukan pada proses penyidikan sesuai KUHAP.

b. Tahap Penyidikan

Masuk dala proses penyidikan makan terduga anggta kepolisian yang melakukan pelanggaran kode etik dan tindak pidana penyalahgunaan narkotika dapat disidik sesuai dengan tempat da atau lokasi kesatuannya. Hal ini dilakukan sesuai dengan aturan KUHAP yang berlaku.

c. Tahap Peradilan Umum

Dalam pemeriksaan di peradilan terdakwa tidak pidana penyalahgunaan narkotika sekaligus anggota kepolisian ini diperlakukan sama dan setara dengan pelaku tindak pidana lainnya sesuai dengan aturan dalam KUHAP. Hal ini sesuai dengan asas semua sama di mata hukum. Terdakwa pun bebas dalam menunjuk advokat atau kuasa hukumnya atau mau disediakan kuasa hukum dari negara.

\section{d. Tahap Peradilan Kode Etik}

Setelah terlewatinya proses di peradilan maka proses selanjutnya yang dilewati oleh terdakwa anggota kepolisian yang menyalahgunakan narkotika adalah bentuk penegakan kode etik profesi Polri. Dalam penegkan kode etik ini yang memiliki peran adalah Propam Polri selaku yang membidangi. Pelanggaran oleh anggota Polri tentunya berakibat hukum,Penyelesaian Pelanggaran Kode Etik Profesi Oleh Kepolisian Republik Indonesia bagi Pelanggar Tindak Pidana Kesusilaan harus melalui beberapa Tahapan penegakan KEPP yang meliputi:

1) Pemeriksaan Pendahuluan;

2) Sidang KKEP;

3) Sidang Komisi Banding;

4) Penetapan administrasi penjatuhan hukuman; 
e. Pemberhentian Dengan Tidak dikaitkan dengan seni pergaulan manusia,

Hormat

Dengan terbuktinya anggota

kepolisian tersebut telah melanggar kode

etik menurut Propam, maka akan dilakukan

penegakan kode etik dengan pemberhentian

tidak hormat atau dicopot dari kesatuan

Polri. Hal ini juga memberikan tanggungjawab kepada anggota yang

dicopot untuk memegang kerahasian dalam

satuan Polri setelah dia dicopot dari

kesatuan.

Pemberian bentuk pemidaan merupakan tahap penetapan dan pemberian sanksi pidana serta dalam hukum pidana diksi pidana memiliki pemahaman sebagai hukum sedangkan pemidaan memiliki pemahan sebagai bentuk penghukuman. ${ }^{9}$ Etika akan memberikan semacam batasan atau standar yang akan mengatur pergaulan manusia di dalam kelompok sosialnya. Dalam pengertian yang secara khusus

${ }^{9}$ L. Marpaung, Asas Teori-Praktik Hukum Pidana. (Jakarta:Sinar Grafika,2005) hlm 23 etika ini kemudian diwujudkan dalam bentuk aturan (code) tertulis yang secara sistematik sengaja dibuat berdasarkan prinsip-prinsip moral yang ada pada saat yang dibutukan akan bisa difungsikan sebagai alat untuk menghakimi segala macam tindakan yang secara logikarasional umum (common sense) dinilai menyimpang dari kode etik. ${ }^{10}$

Dengan demikian etika adalah refleksi dari apa yang disebut dengan pengendalian diri sesuatunya dibuat dan diterapkan dari dan untuk kepentingan kelompok sosial (Profesi) itu sendiri. Oleh karna itu dapat disimpulkan bahwa sebua profesi hanya dapat memperoleh kepercayaan dari masyarakat, bilamana dalam diri para elit professional tersebut ada kesadaran kuat untuk mengindahkan etika profesi pada saat mereka ingin memberikan jasa keahlian

\footnotetext{
${ }^{10}$ Rajalahu, Loc.Cit
} 
profesi kepada masyarakat yang memerlukannya. ${ }^{11}$

\section{Faktor penghambat dan upaya dalam}

Penegakan Hukum terhadap Anggota

\section{Kepolisian Yang Melanggar Kode Etik}

Menurut Soerjono Soekanto,

penegakan hukum dalam kode etik profesi dipengaruhi oleh factor sebagai berkut, yaitu: ${ }^{12}$

a. Faktor hukum atau peraturan perundang-undangan;

b. Faktor aparat penegak hukumnya, yakni pihak-pihak yang terlibat dalam proses pembuatan dan penerapan hukumnya, yang berkaitan dengan masalah mentalitas;

c. Faktor sarana atau fasilitas yang mendukung proses penegakan hukum;

Kode Etik Profesi Polri juga tidak terlepas dari faktor yang saling terkait dengan eratnya karena merupakan esensi

\footnotetext{
${ }^{11}$ Ibid, Hlm 146

${ }^{12}$ Soekanto, Loc. Cit
}

dari penegakan hukum itu sendiri. Mulai dari faktor hukumnya, faktor penegak hukumnya, faktor masyarakat dalam hal ini anggota Polri sebagai objek dari penegakan hukum Kode Etik Profesi Polri dan faktor kebudayaan dalam organisasi Polri maupun dalam masyarakat pada umumnya, dan untuk mengetahui sejauh mana faktor tersebut sebagai tolak ukur bagi efektivitas penegakan hukum Kode Etik Profesi Polri. Berangkat dari teori inilah faktor-faktor yang menjadi mempengaruhi penerapan Kode Etik Profesi Kepolisian.

Faktor-faktor yang dihadapi dalam penegakan hukum memiliki empat (4) faktor sebagai berikut:

1) Faktor Hukum

Masalah penyimpangan polisi di Indonesia pada dasarnya telah diantisipasi oleh Polri melalui berbagai instrumen pengawasan terhadap personil polisi. Pertama, melalui keberadaan instrumen legal berupa peraturan. Selain pelanggaran 
pidana yang secara umum diatur dalam KUHP, dalam melaksanakan fungsi pengawasan terhadap personilnya, Polri memiliki dua landasan utama yaitu melalui keberadaan peraturan disiplin dan kode etik profesi. Peraturan disiplin anggota Polri diatur melalui PP No. 2 Tahun 2003. Landasan kedua adalah kode etik profesi yang diatur dalam Peraturan Kapolri Nomor

14 Tahun 2011. Permasalahannya adalah sulit untuk memisahkan secara tegas antara berbagai aturan intern tersebut, selalu ada warna abu-abu, selalu ada sisi terang dan sisi gelap, akan selalu ada tumpang tindih antara berbagai aturan tersebut. Permasalahan lain selain masalah di atas adalah seringnya peraturan yang mengatur tentang Kode Etik Profesi Kepolisian ini dilakukan perubahan. Sebagaimana diketahui sebelum ditetapkannya Peraturan Kapolri Nomor 14 Tahun 2011 tentang Kode Etik Profesi Kepolisian, sebelumnya sudah ada dua Peraturan Kapolri yang mengatur tentang hal yang sama, yaitu Keputusan Kapolri No.Pol: KEP/32/VII/2003 dan Peraturan Kapolri Peraturan Kapolri Nomor 7 Tahun 2006. Artinya, peraturan tentang Kode Etik Profesi Kepolisian ini sudah dua kali mengalami perubahan. Di samping itu, Peraturan tentang Kode Etik Profesi Kepolisian yang baru ini tidak tersedia penjelasan yang memadai bahkan tidak ada penjelasan sama sekali. Akibat peraturan yang multitafsir tersebut masing-masing pihak akan memiliki penafsiran yang berbeda-beda, sehingga dapat membuka peluang terjadinya manipulasi dalam penegakan hukum yang pada akhirnya menimbulkan ketidakpastian hukum.

2) Faktor Sarana atau Fasilitas

Aspek yang tidak kalah pentingnya dalam penegakan Kode Etik Profesi Polri adalah aspek sarana atau fasilitas baik peralatan yang memadai maupun dukungan anggaran keuangan yang cukup.

3) Faktor Anggota Polri 
Anggota Polri sebagai objek dalam penegakan hukum Kode Etik Profesi Polri cukup mempengaruhi keberhasilan dari penerapan kode etik profesi kepolisian. Beragam latar belakang dan karakteristik pribadi yang dimiliki para anggota polisi, turut mempengaruhi tingkat kualitas kinerja masing-masing, ada yang tinggi dan ada yang rendah, yang pada akhirnya sebagai akumulasi akan mempengaruhi tingkat kualitas kinerja, baik latar belakang pendidikan, adat istiadat yang dianut, termasuk beragamnya karakter kualitas emosional dan intelejensia setiap anggota polisi, kualitas mental dan keimanan setiap orang yang juga sangat beragam, belum meratanya tingkat profesionalisme anggota polisi dalam segala tingkatan.

Unsur esensial untuk mewujudkan penegakan hukum yaitu untuk memperoleh kepastian hukum, keadilan, dan manfaat dari penegakan hukum tersebut. Proses penegakan hukum dapat berjalan dengan efektif apabila terbentuk suatu mata rantai beberapa proses yang tidak boleh di pisahkan.

Solusinya, sebaiknya para instansi terkait dapat meningkatkan kinerjanya. Sehingga tidak terjadi tumpang tindih dan saling menyalahkan akan terjadinya suatu keadaan dalam strata kehidupan masyarakat, apalagi itu terjadi di tubuh dan badan polri. Ketika setiap pihak dan instansi terkait dapat melihat dan mengembangkan setiap kekurangan yang ada, maka diyakini tidak akan ada kecurangan, dan kemudian dapat terjadi kesetaraan dalam kinerja setiap abdi negara khususnya dalam hal kinerja pihakpihak anggota kepolisian.

Upaya yang dilakukan untuk mengatasi faktor-faktor dalam Penegakan Hukum Bagi Anggota Kepolisian Yang Melanggar Kode Etik adalah hukum yang hidup melalui polisi ini, janji-janji dan tujuan hukum untuk mengamankan dan melindungi masyarakat menjadi suatu 
kenyataan. Sebagai suatu profesi maka di dalam kepolisian diperlukan upaya pemolisian profesi, karena polisi merupakan suatu pekerjaan yang memiliki kedudukan yang strategis dalam bidang penegakan hukum. Profesi Polri memiliki standar persyaratan yang bermacam-macam dalam bidang perekrutannya dan merupakan salah satu organisasi yang mengembangkan sendiri suatu pengetahuan teoritis. kepolisian juga merupakan suatu badan yang mempunyai dan melaksanakan kode etik dan memiliki otonomi politik untuk mengontrol nasibnya sendiri. kode etik diperlukan untuk melindungi kalangan profesi ini dari hal-hal yang tidak diinginkan.

Dari penjelasan di atas, kode etik juga dapat berfungsi sebagai alat perjuangan untuk menjawab persoalan-persoalan hukum yang ada di dalam masyarakat.wujud kode etik polri tersebut sangat erat kaitannya dengan tugas dan fungsi Polri yaitu menjaga ketertiban, keamanan, dan kesejahteraan masyarakat. kode etik yang dimiliki Kepolisian Republik Indonesia tidak bisa lepas dari keberadaannya sebagai pengayom masyarakat, sehingga hubungan antara masyarakat dan Kepolisian harus berjalan dengan erat dan baik, karena akan mustahil, kode etik polri terwujud apabila masyarakat tidak bisa diajak bekerjasama. tentunya juga, Kepolisian dalam menjalankan kode etik Kepolisian harus memahami prinsip-prinsip etika profesi luhur Kepolisian.

Sebagaimana dijelaskan dalam point sebelumnya bahwa ada faktor-faktor yang dihadapi dalam penegakan hukum dalam pelanggaran kode etik, namun hal tersebut tentu seharusnya tidak menjadi hambatan bagi anggota polri untuk tetap melakukan tugasnya, upaya-upaya yang dilakukan oleh ialah sebagai berikut:

\section{Faktor Hukum}

Faktor hukum ditemukan sebelumnya menjadi hambatan dalam penegakan hukum yang dilakukan oleh 
Propam, dalam hal tersebut Propam didapati masih juga kebingungan dalam melakukan penyelesainnya tetapi tetap menggunakan undang-undang yang berlaku dan kode etik yang sesuai dengan pelanggaran yang dilakukan oleh oknum kepolisian.

\section{Faktor Sarana dan Prasarana}

Sarana dan prasarana yang masih

dirasa kurang untuk memproses penegakan hukum kode etik yang dilaksanakan, dimana hal tersebut bisa dilakukan dengan kerjasama antara unit-unit lainnya sehingga faktor yang dihadapi sarana dan prasarana menjadi berkurang dan bisa terselesaikan.

\section{Faktor Anggota Polri}

Faktor yang dihadapi ini bisa diselesaikan dengan cara masing-masing anggota Polri bersinergi dan mempunyai semangat kerja yang sama dalam setiap pekerjaan sehingga membantu unit-unit lainnya untuk selalu tetap prima dalam memberikan penegakan hukum di luar institusi maupun di dalam institusi khususnya kode etik, dengan perintah dari atasan seharusnya hal tersebut menjadi acuan untuk tercapainya tujuan yang sama demi Polri yang profesional.

Menurut penulis, hukum tetap harus ditegakkan, walaupun oknum anggota yang terkait kasus hukum narkoba sudah sadar pakai narkoba dan merupakan anggota Polri, tetap harus diproses hukum secara adil dan transparan, Perlunya peran pengawasan internal Polri dimaksimalkan. Misalnya secara periodik Polri melakukan tes urine terhadap anggotanya sebagai langkah deteksi awal. Apresiasi yang tinggi diberikan terhadap sikap tegas Polri memecat anggotanya yang terlibat narkoba. Pengawas internal seharusnya juga jangan main mata atau tutup mata terhadap penyimpangan yang dilakukan anggota.

\section{Penutup}

\section{Kesimpulan}

1. Ketentuan mengenai Kode Etik Profesi Polri sebagaimana diatur dalam 
Peraturan Kapolri No. 7 tahun 2006 dan

Peraturan Kapolri No.8 Tahun 2006, merupakan kaidah moral dengan harapan tumbuhnya komitmen yang tinggi bagi seluruh anggota Polri agar mentaati dan melaksanakan (mengamalkan) Kode Etik Profesi Polri dalam segala kehidupan, namun kenyataan masi ada beberapa anggota polri bertindak sebaliknya yang tidak sesuai dengan etika profesi kepolisian Atau dalam arti kata lain masi ada sebagian polisi melakukan pelanggaran terhadap kode etik profesi kepolisian Dalam pelanggaran kode etik seperti salah satu contoh penyalahgunaan narkoba, yang tentu saja melanggar kode etik Polri, maka penegakan hukum harus dilaksanakan sesuai dengan hukum yang ada dan tentu saja dengan kode etik yang dimiliki oleh Polri atau dengan cara melalui aturan hukum yang berlaku.
2. Faktor-faktor yang dihadapi dalam penegakan hukum terhadap polisi yang melanggar kode etik berupa faktor hukum yang masih tumpang tindih, faktor anggota yang masih dirasa kekurangan dengan permasalahan, faktor sarana dan prasarana yang menjadi faktor yang dihadapi dalam penanganan penegakan hukum, Faktor anggota Polri yang disampaikan tidak semua satu visi misi dalam penyelesaian kinerja yang dihadapi. Faktor-faktor tersebut mempunyai upaya dalam penangananya, seperti faktor hukum yang dihadapi dengan cara memakai peraturanperaturan sesuai, faktor anggota yang dianggap kurang dihadapi dengan cara bersinergi dengan unit-unit lainnya dan juga penambahan anggota Polri yang baru tentu saja membantu hal tersebut, kemudian faktor sarana dan prasaran yang dibantu dengan unit-unit lainnya dan peningkatan sarana-prasaran 
kedepannya dan kemudian yang terkahir faktor masyarakat dan anggota Polri yang diselesaikan dengan penyamaan visi misi dari anggota Polri tersebut.

\section{Saran}

Adapun saran yang dapat diberikat dalam pelaksanaan penegakan hokum bagi anggota kepolisian yang melanggar kode etik dalam penyalahgunaan narkotika adalah sebagai berikut:

1. Saran kepada penegakan hukum dan pelanggaran kode etik sudah bagus namun agar lebih proaktif terhadap anggotanya dalam menangani kasus kode etik sehingga penegakan hukum tersebut menjadi lebih lancar.

2. Agar memenuhi faktor-faktor yang dihadapi oleh anggota Propam maka supaya pemecahan masalah ini secepatnya dan akan menjadi tolak ukur dengan membawa citra Polri yang baik di mata masyarakat, bukan hanya menindak dan melayani masyarakat namun juga internal yang terus membaik akan membawa hal positif lainnya.

\section{Daftar Pustaka}

\section{Buku}

Abdulkadir, Muhammad, 2004, Hukum dan Penelitian Hukum, Bandung: Citra Aditya Bakti.

Adi Koesno, 2009, Diversi Sebagai Upaya Alternatif Penanggulangan Tindak Pidana Narkotika Oleh Anak, Malang, UMM Press.

Adi Kusno, 2014 , Diversi Tindak Pidana Narkotika Anak , Malang: Setara Press.

Alam, Wawan Tunggul, 2004, Memahami Profesi Hukum: Hakim, Jaksa, Polisi, Notaris, Advokat Dan Konsultan Hukum Pasar Modal, Jakarta: Milenia Populer.

Arif, Barda Nawawi, 2008, Bunga Rampai Kebijakan Hukum Pidana, Jakarta. Kencana

Atmasasmita, Romli, 1997, Tindak Pidana Narkotika Transnasional Dalam Sistem Hukum Pidana Indonesia, Bandung: Citra Aditya Bhakti.

Bambang, Waluyo, 2008, Pidana dan Pemidanaan, Jakarta: Sinar Grafika.

Friedman M. Lawrence penerjemah Wisnu Basuki, 2001, American Law An Introduction Second Edition, Jakarta: Tatanusa. 
Ibrahim, Johnny, 2005, Teori dan Metodologi Penelitian Hukum, Jakarta: Bayu Media Publishing.

Marpaung, L. 2005 Asas Teori-Praktik Hukum Pidana. Jakarta:Sinar Grafika

Muladi, 1995, Kapita Selekta Sistem Peradilan Pidana, Semarang: Badan Penerbit Universitas Diponegoro.

Rifai Achmad, 2014, Narkoba Di Balik Tembok Penjara, Yogyakarta: Aswaja Pressindo.

Sasangka, Hari, 2003, Narkotika Dan Psikotropika Dalam Hukum Pidana, Bandung: CV. Mandar Maju.

Soekanto, Soerjono dan Mamudji, Sri, 2003, Penelitian Hukum Normatif: Suatu Tinjauan Singkat, Jakarta: PT. RajaGrafindo Persada.

Utomo, Warsito Hadi, 2005, Hukum Kepolisian Di Indonesia, Jakarta: Prestasi Pustaka.

\section{Artikel Jurnal}

M. Pradhana, 2018, Pertanggungjawaban Pidana Terhadap Anggota Polri Yang Melakukan Tindak Pidana Penyalahgunaan Narkoba Studi Putusan Nomor 128/PID/SUS/2014/PN.TK),Lampung: Skripsi.

Rajalahu, Yanius, 2013, Penyelesaian Pelanggaran Kode Etik Profesi Oleh Kepolisian Republik Indonesia, Jurnal Lex Crimen Vol 11/No.2

\section{Peraturan Perundang-Undangan}

Undang-undang Nomor 2 Tahun 2002 Tentang Kepolisian Negara Republik Indonesia
Undang - Undang Nomor 35 Tahun 2009 tentang Narkotika.

Undang - Undang Nomor 48 Tahun 2009 tentang Kekuasaan Kehakiman.

Undang - Undang Nomor 8 Tahun 1981 tentang Hukum Acara Pidana.

Peraturan Pemerintah Nomor 58 Tahun 2010 Tentang Pelaksanaan Kitab UndangUndang Hukum Acara Pidana

Peraturan Pemerintah Nomor 1 Tahun 2003 Tentang Pemberhentian Anggota Polri.

Peraturan Pemerintah Nomor 2 Tahun 2003 Tentang Peraturan Disinlin Anggota Kepolisian Republik Iesia.

Peraturan Pemerintah Nomor 3 Tahun 2003 Pelaksanaan Teknis Institusional Peradilan Umum Bagi Anggota Kepolisian Negara Republik Indonesia

Peraturan Kapolri Nomor 14 Tahun 2011 Tentang Kode Etik Profesi Polri.

Peraturan Kepala Kepolisian Negara Republik Indonesia No. Pol. : 7 Tahun 2006 Tentang Kode Etik Profesi Kepolisian Negara Republik Indonesia.

Surat Edaran Badan Narkotika Nasional R.I. No. 03/IV/2002/BNN ertanggal 22 April 2002. 